\title{
Textuality, Heritage, and Identity in Hungary: \\ Contexts for the Interpretation of Szikszai's Insertion in Macbeth (2018)
}

\author{
Zsolt Almási
}

\begin{abstract}
The present essay explores the textual politics and politicised textuality in Rémusz Szikszai's Macbeth, which premiered in a public theatre, the Jászai Mari Theatre, Tatabánya, Hungary in 2018, then in 2019 moved to the Szkéné Theatre, Budapest. In the focus of this exploration is a textual insertion by the director which took the form of Duncan's speech regarding changing the method of succession in Scotland. This insertion is analysed in light of interpretive traditions in the context of changes in Hungarian theatre culture since 1989, the relationship between the theatre and the state, and especially in the context of political tropes appearing in Shakespeare productions. Two conclusions will follow from the analysis with respect to the added text. The first of these is connected to the moderately liberal textual strategy of this insertion, which is responsible for the political orientation of the production. The second is the reconsideration of the gravity of the insertion appreciated in a larger historical context as well as in the particular context of the production.
\end{abstract}

\section{Key words}

Macbeth, Rémusz Szikszai, Jászai Mari Theatre, Szkéné Theatre, Duncan, playtext, insertion, politics, translation, adaptation 
'We won, so we do this, / We do this, because we can, / We do this, because this is our duty' (SZIKSZAI 2018: 15) claims Duncan in Rémusz Szikszai's Macbeth when announcing that Malcolm will be the Prince of Cumberland and will succeed him on the throne of Scotland. These lines along with a dozen others included here are not familiar for audiences, as they are neither in the Hungarian translations of the play nor in the English texts. This is Szikszai's insertion to the playtext for a production directed by him which premiered in 2018 at the Jászai Mari Theatre, a large public facility in Tatabánya, Hungary, then moved in 2019 to the Szkéné Theatre, Budapest.

In this paper, I shall explore and contextualise this insertion so as to show what has made this production appreciated by critics and audiences alike, and also to place it within the inertia systems of the living cultural heritage and identity of the nation. This textual insertion will be used to illustrate the methods of politicising Shakespeare in Hungarian public theatres. The method for the exploration of the insertion will lie in an analysis of the English version in light of two trends of reading and interpreting the play itself. I will then move on to contextualisation of the text in terms of the current political situation, the textual politics in creating the playtext, the complicated relationship between the theatre and the state, and, finally, its place in the production itself. All this will boil down to two claims. The first of these is connected to the moderately liberal textual strategy of this insertion, which is responsible for the political orientation of the production. The second is reconsideration of the gravity of the insertion if the production is appreciated in a larger historical context as well as in the particular context of the production.

\section{Reading the English text}

In the original text, Malcolm's succession is presented in a rather simple and straightforward manner. Duncan has nominated Macbeth the Thane of Cawdor, as the witches predicted earlier. The third prophecy though is still hanging in the air, but seems impossible to come true after all. Ironically right after Macbeth's promotion, Duncan nominates his son, his heir Malcolm, the Prince of Cumberland:

- Sons, kinsmen, thanes,

And you whose places are the nearest, know

We will establish our estate upon

Our eldest, Malcolm, whom we name hereafter

The Prince of Cumberland; which honor must

Not unaccompanied invest him only,

But signs of nobleness, like stars, shall shine

On all deservers.- (Macbeth 1.4.41-48)

Duncan's words and acts seem to suggest that in the world of the Scottish tragedy, the succession was not primogeniture. Apparently, the method of succession as described 
by Holinshed was tanistry ("where by the old laws of the realm, the ordinance was, that if he that should succeed, were not of able age to take the charge upon himself, he that was next of blood unto him should be admitted') (Holinshed quoted in WOFFORD 2017: 519). In contrast with tanistry, the new method lies in the firstborn of the present monarch being offered the title of the Prince of Cumberland, and by this designated to the crown after the demise of the father. As Susanne Wofford explains: 'since from about the eighth century on, Scottish kings had been chosen from alternating aristocratic families [...] [t]he Scottish system of tanistry essentially alternated the monarchy between members of the southern and northern Scottish clans, helping thereby to keep the provinces united against the Hostile Danes, English, and Norwegians' (WOFFORD 2017: 520). In this respect, after Macbeth's defence of the country from foreign and internal enemies, and with him being the leading northern thane against the southern Duncan, the nomination of Malcolm, who has not been represented as a battle hero, could well have come as a shock for Macbeth. This change of method from tanistry to primogeniture, from tribal to feudal, is announced in eight lines without explanation or apology. The shock as a result of the nomination along with the method would be rather understandable.

The jolt would be lessened, however, if we concentrate exclusively on the original text of the play. As Sheldon P. Zitner observes: 'The question of elective succession to the throne is not emphasised (for this would tend to justify Macbeth's claim to the throne and thus in some slight measure extenuate his guilt)' (ZITNER 1964: 26). The textual lack of emphasis on the change of method regarding succession may also imply that the change is not that important, that it can be taken for granted and, after all, is not that shocking.

This act of altering the political system may well be contextualised in two trends of reading the play, one which can be considered traditionalist, the other revisionist. In a more conventional approach the play is contextualised in dualisms: Macbeth versus Duncan, versus Banquo, versus Malcolm. In this reading, as Kolin interprets, Malcolm is 'Christ-like,' or a 'Christ-conqueror' (KOLIN 1974: 159). Or if Duncan is presented as a benevolent and successful king, a king who understands his rule as something positive and himself as an object of admiration, he is like God who rejoices over his creation, his world. This reading would almost necessarily cast a darker shadow on the deeds and thoughts of Macbeth; they would be taken as more immoral, with the murder seen as regicide imitating Satan's rebellion against God, or a firstborn son's murderous instincts towards the father-figure. This traditional approach is, however, not relegated to the past. As Francesca Cauchi claimed:

It is this dualist resurgence, and in particular that of the good Scot Banquo/bad Scot Macbeth, which my essay seeks to augment. Through a new close reading of key passages, conscience will once again be seen to occupy its center-stage position as the play's unequivocal moral compass upon which the Banquo-Macbeth duality is predicated. (CAUCHI 2015: 336) 
The revisionist approach, often in contrast to the dualistic approach, focuses more on abstract structural elements or historical approaches. This stance would argue that Duncan is located at the other end of the scale, as a king who is completely at odds with reality and who cannot read the minds of his subjects, from the Cawdors to Malcolm. In the words of Rebecca Lemon 'the opening scenes of the play expose Duncan's political ineptitude, borne of his inability to read the political landscape that surrounds him' (LEMON 2002: 37-38). And thus, he is admirable neither as a king nor as a man. On a more balanced note, Géza Kállay presents Duncan as a political ruler who is attempting to balance Scotland between two mighty thanes, Macbeth and Banquo, in nominating his son as his successor (KÁLLAY 2002: 156). In this revisionist trend, the interpretation of the Macbeths will be more ambiguous, and their crimes will appear in a more refined light. Szikszai's production can be associated with this latter approach, especially with respect to the nomination speech.

\section{Szikszai's insertion}

The director inserted twenty-eight lines in loose iambic pentameter, or rather in its Hungarian equivalent, regarding tradition and the new method of succession. ${ }^{1}$

1 We shall found our later empire on our eldest son;

We, hereby, nominate our eldest son, Malcolm,

The heir of our crown, and elevate him

To be the prince of Cumberland.

This title will belong to the first born of Scottish kings.

From this day, from this time on we shall not elect the king!

We shall not play at equality anymore,

Which has become the source of our divisions and rebellion!

We shall forget this outworn custom,

Outworn by the constant naysayers.

It is holy conviction

And love for our country that guide us,

When we change the customary law,

And we create a new homeland.

Honouring our ancient customs,

We shall build a new country upon the old.

Our descendants will bless our names for this;

For our grandchildren and

their sons, this is going to be

The foundation of order,

Tradition and life, and that we do this,

They will include our names in their prayers.

But this honour is not going to

Belong to my son only, but the gentle star

will shine upon all the loyal.

We won, so we do this,

We do this because we can,

And we do this because this is our duty.

(All translations are my own unless otherwise stated.) 
This speech clarifies, on the one hand, the new method of succession with an exploration of the past, and on the other, the justification of the present method. Duncan explains in this speech that in the past there were once elections based on equality, which, however, has proven ineffective and even pernicious, thus the need has arisen for a new method of primogeniture.

What is even more fascinating in this speech than its conclusiveness is the rhetoric of the annunciation of the new method, with the language of religion, patriotism, and absolute power employed. Duncan here uses religious expressions such as 'holy conviction', 'our descendants will bless our names', and they 'will include our names in their prayers'. The religious layer of the speech is complemented with a patriotic layer when he refers, e.g., to his 'love for our country'. He claims that 'we create a new homeland', and that he 'honours the ancient customs' of his country, while he has just abrogated them. Further, he conveys almost cheekily his absolute power: 'we will not play at equality anymore', thus the apparent democratic state was just a game, played by everybody without serious belief in it. To further the autocratic rhetoric, Duncan ends his speech with an enhanced emphasis on the unrestricted power of the winner: 'We won, so we do this, / We do this, because we can, / We do this, because this is our duty'. The winner, thus, can do anything, like doing away with the childish game of equality; his power legitimises anything, no one can oppose him and, moreover, he has no other option but to act accordingly.

These rhetorical layers of the speech may well be construed as a reference to the political discourse of the Orbán administration. Both the communicative strategies and the actions of the government have been taken by many as arrogant, as decisions and their execution have seemingly been carried out through brute force owing to having won elections in 2014 with a two-thirds majority in Parliament, which was reinforced again in 2018 with the same majority. This reference may sound all too literal, but read in the context of the heritage of the Communist and post-Communist periods it may well be interpreted in a somewhat more complicated way with regards to the textual politics and the political implications of the play.

\section{Szikszai's insertion and theatrical textual politics}

First of all, with regard to the text, Szikszai's insertion strikes a middle way in terms of the practice of Hungarian directors toward textual intervention. This insertion can be classified as moderately liberal - first, in light of the history and legacy of the textual politics going back to the Communist era. This heritage is a side effect of the doublespeak (see also FÖLDVÁRY in this collection) that emerged from the 1950s in the Hungarian theatre, a phenomenon that emerged owing to the varying waves of harsh state control of the Socialist regime. During the Socialist era no play could be performed without an official license, which was more easily obtained for a production of a work by a classical and canonical author like Shakespeare than the dramas of modern, contemporary writers, especially from the West. This is, of course, not true for 
every work by a canonical writer, with one interesting exception being The Merchant of Venice, which was neglected due to the taboos of the Socialist regime (IMRE 2018). As the canonised translations were established, directors could delete or reorganise lines, even scenes or characters, but otherwise the text was not to be modified. Social criticism could only emerge through the placement of lines and how they were delivered by performers. The prevailing circumstances could add a further layer of significance constituting a wink towards the audience, and a feeling of community in that the performers could rely on the audience to interpret the clues, implying that the performance meant something here that could not be directly told. This conservativism with respect to choosing works and a reduced amount of attention to the text itself ossified into a conservative attitude towards playtexts in general.

Near the end of the Communist regime, along with other cultural phenomena a more liberal attitude towards the playtexts came to be accepted. This liberalisation can be seen to boil down to three causes. First, as literature beyond the Berlin Wall was treated as reactionary, these literary works could not even be translated into Hungarian, or if so, with parts left out from the translations that did not harmonise with the priorities of the Socialist cultural politics. When the political climate in the second half of the 1980s became less tense, a cultural vacuum appeared which brought a need for these works to appear in Hungarian. With political freedom there came into being a fever of translations in the 1990s; dozens of foreign language books were translated into Hungarian in an attempt to catch up with Western culture. Although haste naturally led to mixed results and harsh criticism, at least a welcome outburst of literature from the West was pouring into Hungarian culture.

Secondly, this general tendency had its reverberations in relation to Shakespeare as well. New translations began to appear, but strangely enough these were not taken in opposition to previous translations. The new translations did not intend to compete with classical translations on the page; first and foremost they were requested by directors for specific productions with the intention to recreate a Shakespearean text easily recitable on the stage and that is easily understood by the audience, which was not necessarily the case with the canonised $19^{\text {th }}$-century translations. The earliest new translations were not particularly daring; for example, the new translations of Hamlet by István Eörsi (1983, Csiky Gergely Theatre, Kaposvár, dir. Tamás Ascher) and Dezső Mészöly (1996, New Theatre, Budapest, dir. János Ács) were partial translations, and audiences rather disliked them. The new complete translations, such as those of István Eörsi (2003, Csiky Gergely Theatre of Temesvár, dir. Victor Ioan Frunză), Ádám Nádasdy (1999, Csokonai Theatre, Debrecen, dir. György Lengyel) were received well in the theatre, but were resisted by critics, who had long experience as men of literature (TABI 2018). By now these translations have appeared on the printed page (see, e.g., SHAKESPEARE 1993, 2012) as well, thus providing alternatives to the classical translations as well as becoming the canonised translations in their own right.

In line with the multiplicity of translations, more and more directors requested even newer translations for specific audiences; translators also began to render the text for productions with a novel freedom. The most famous adaptors, rather than 
translators, of Shakespearean texts in the theatres and most controversial among scholars are Dániel Varró, for example his translation of The Taming of the Shrew (2012, Comedy Theatre, dir. Péter Gothár), and Péter Závada, who adapted Ádám Nádasdy's translation of As You Like It for a teenage audience at the Katona József Theatre (dir. Dániel D. Kovács) in 2016. Among many others, these rather adapted texts illustrate a novel and extremely liberal attitude to Shakespearean texts. On a more abstract level, Zsuzsa Radnóti describes how 'since the 1970s the relationship between the written word and the director changed radically, from the humble interpreter of the literary dialogue, the director became the maverick creator manipulating the text without inhibitions' (RADNÓTI 2005: 258).

Between the conservative and liberal end of textual politics of the second decade of the $21^{\text {st }}$ century one may find a production of King Lear. In 2013 Bertalan Bagó directed a King Lear at the Vörösmarty Theatre, Székesfehérvár, for which two translations formed the textual basis of the playtext: Mihály Vörösmarty's classical $19^{\text {th }}$-century

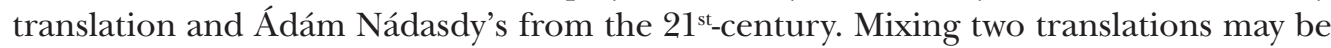
interesting in itself, but Bagó created a production, in which instead of only mixing the two translations randomly, he also thematised the choice between classical and modern translations. The older generations of the characters spoke in $19^{\text {th }}$-century Hungarian while the younger generation recited their lines in Nádasdy's contemporary Hungarian until mid-performance. In the second half of the performance the older generation of the characters gradually shifted to Nádasdy's version, bringing the two generations closer to each other.

Within this spectrum of textual attitudes, Szikszai's playtext does not display radical textual politics. To make the speeches flow, to be as clear as possible in terms of meaning, and also to maintain the lines from the play that audiences already knew, Szikszai used three modern translations: Lőrinc Szabó's version from 1939, Imre Szabó Stein's from 2001, and Géza Kállay's more recent one from 2014. With this multiplicity of translator voices and in the context of contemporary composition of the playtext, insertions, especially ones cast into loose iambic pentameter, do not emerge as strange during the production. This is all the more so because the audience is already prepared for liberties being taken with the text, as the performance opens with Macbeth pointing a camera at himself to stream his recital of Sonnet 129 on a large screen on the stage.

Similarly to the textual politics, the political assertions of the performance take on a different shade of meaning once contextualised in three other aspects of the production. First, the stage design creates a more symbolic context for the play. Secondly, the stage design is spiced up with costumes corroborating a contemporary political reading of the scene. Third, the political references through the choice of costumes become even more pointed with Malcolm's immorality in this production.

The stage design in this production consists in multipurpose, huge clay boxes that create a symbolic and timeless world for the play. These boxes occasionally function as pillars, e.g., during Duncan's speech, or as a bed or a bath. At times they are used to hide or reveal characters, at other times more symbolically as a womb to hide or reveal Macbeth in a foetal position. Characters (witches, Macbeth, Lady Macbeth) crawl into 
the world of the stage through them. These large clay boxes furthermore represent constant liminality, a sort of uncanny and suffocating uncertainty, as if they represented something similar to what Tünde Incze describes regarding the spaces in Macbeth: 'The flat Globe in Macbeth indicates planes are pressed against each other, and the human inhabited world turns into hell [...]'(INCZE 2003: 143).

The stage design during Duncan's speech perfectly represents the power relationship between the characters, who thus corroborate the autocratic overtones of Duncan's speech about the succession. During the announcement, Duncan towers above the rest of the characters from behind a tall black rostrum. The pillars on each side of this podium and thus the kingdom are Macbeth and Banquo standing next to it below Duncan. Malcolm, the newly made future king is standing in the background at the same level as his father on something like huge stairs like a climber with a pinch of egotism on his face.

This stage design is further complemented by the costumes: the warriors (Macbeth and Banquo included) in their battle gear are still bloody (in this production blood is greyish white). Duncan wears an elegant modern-looking jacket and kilt, which points towards his liminal position in terms of succession. Surrounded with the still bloodsmeared soldiers, his elegance and unsullied appearance indicate the lack of his personal involvement in the war. Among the seeming Scottish characters, Malcolm sticks out with his expensive modern suit, a garment that is neither traditional nor Scottishlooking, which suggests that Malcolm is a politician rather than a future king, and few considerations other than his personal advancement and ambition motivate his actions, none of which have anything to do with the welfare of Scotland.

Malcolm stands out not only because of his suit and the symbolic order during the nomination speech but because of his acts as well. He does not take part in defending Scotland at all in this production; he is always well-dressed in a suit, an outsider who remains outside of the carnage going on in Scotland. When talking to Macduff in Act 4, he presents himself as an immoral person perhaps not truthfully, but purposefully.

\section{MALCOLM}

It is myself I mean, in whom I know

All the particulars of vice so grafted

That, when they shall be opened, black Macbeth

Will seem as pure as snow, and the poor state

Esteem him as a lamb, being compared

With my confineless harms.

\section{MACDUFF}

Not in the legions

Of horrid hell can come a devil more damned

In evils to top Macbeth. 


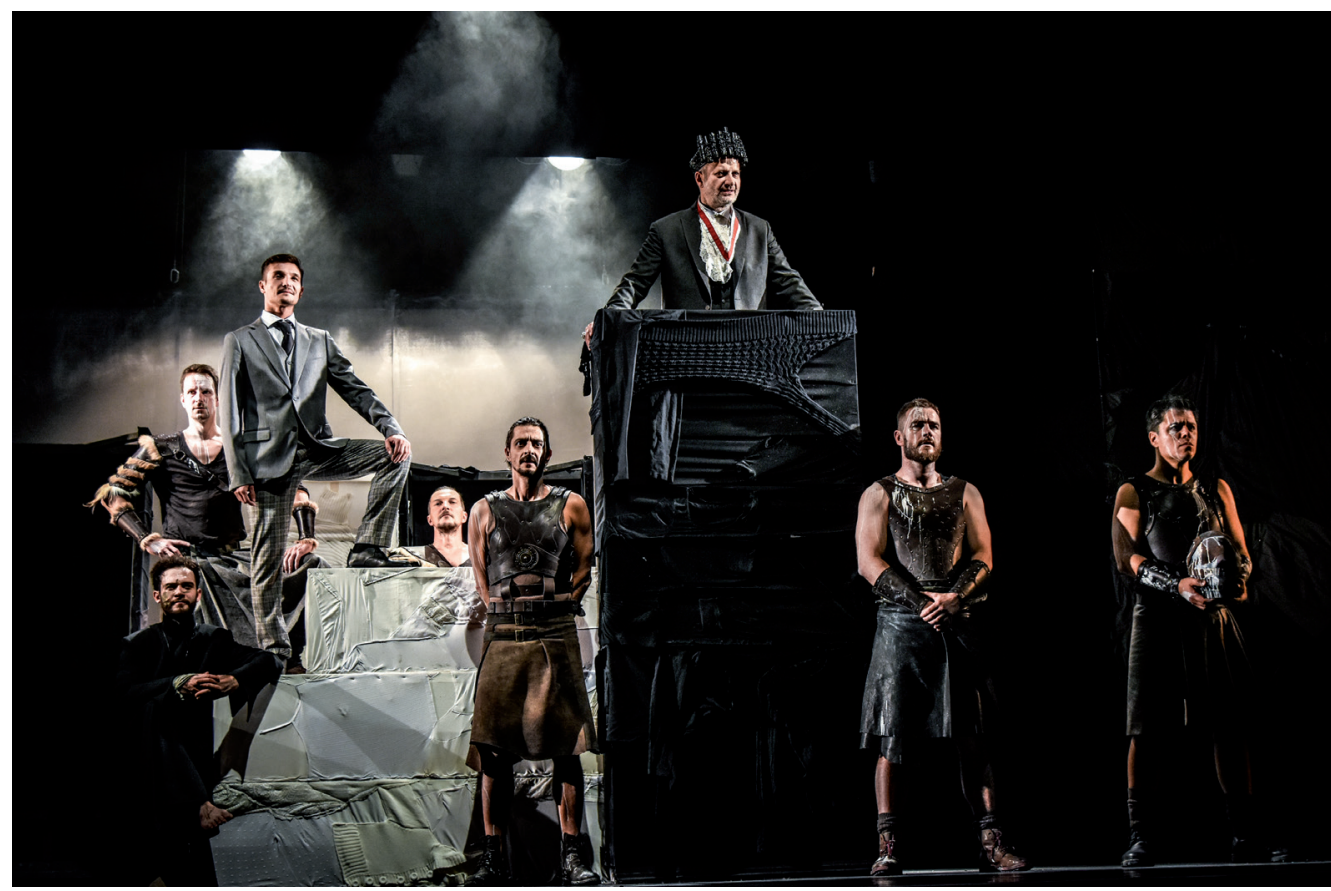

Fig. 1: Bence Figeczky, Balázs Dévai, Gergő Mikola, Attila Maróti, Gábor Nagypál, Róbert Kardos, Attila Király, and Rodrigo Crespo (from left to right).

Source: Jászai Mari Theatre, Violetta Prokl.

\section{MALCOLM}

I grant him bloody,

Luxurious, avaricious, false, deceitful,

Sudden, malicious, smacking of every sin

That has a name. But there's no bottom, none,

In my voluptuousness. Your wives, your daughters,

Your matrons, and your maids could not fill up

The cistern of my lust, and my desire

All continent impediments would o'erbear

That did oppose my will. Better Macbeth

Than such an one to reign. (Macbeth 4.3.61-79)

These claims in the Shakespearean play appear as a way of testing Macduff's loyalty, his dedication to Malcolm, to the anti-Macbeth league, to the new regime, i.e., 'the exact limits of Macduff's offered support' (RAMSEY 1973: 294). But even here, the revisionist trend locates something uncanny. If this is a test, then, as Rebecca Lemon claims: 'Using deception to test Macduff's loyalty and triumph over Macbeth, Malcolm adopts the traitor's art' (LEMON 2002: 40). In Zitner's words: 'For what emerges from 
it is Malcolm's premise (not only his suspicion, but his certainty, of how far "good" men will go in accepting and conniving at evil), and a justification of that premise (how far Macduff actually does go). The scene precisely fixes the behavioral scale of the play, and it does so only shortly before we are to make our final evaluation of Macbeth' (ZITNER 1964: 23).

In a possible correlation with this revisionist reading of Malcolm's words and deeds, in Szikszai's production this speech is delivered as Malcolm climbs out of a bath where young women caressed him with explicitly erotic overtones. To make matters even worse, the young actresses double in the witches' parts, confirming that the immorality in Malcolm's self-description is anything but deceptive. And it is this honesty that is supposed to test Macduff, and he is ready to gain Malcolm's trust, which really fixes the behavioural scale of the play for good.

All these factors, the structure of the stage design, set pieces, the costumes in tune with Malcolm's clear immorality heighten the effect of Duncan's autocratic behaviour. It is not so surprising then that this suffocating immorality of the projected world frustrates Macbeth rather deeply. And it is this frustration that provides further reasons to him to seize the crown. This, however, does not make Macbeth guiltless, but partly relocates the moral anxieties of the production from Macbeth more generally to the Scottish political world.

Duncan's changing the system of succession on the fly along with Malcolm's alleged immorality may well allude to some features of political behaviour in Hungary resulting from the two-thirds majority in the parliament. Insofar as some national and international news agencies are concerned, the Orbán administration more often than not is labelled as autocratic. The method of legal changes has been criticised in the case of, for example, the introduction of the New Fundamental Law in 2011-2012, the changing of electoral districts as well as many other larger (restrictions on CEU, the Hungarian Academy of Sciences, University of Theatre and Film Arts) and smaller issues. What has been criticised besides these decisions and changes is the method in which these decisions and changes were carried out, i.e., without reaching out to stakeholders, without other parties involved. Also, the daily press often calls attention to nominations for which the new nominee can be thought of as not the best choice in terms of education, previous activities, lack of substantial achievements, etc. Naturally, sometimes this labelling may be subjective, and there may be different perspectives and agendas supporting the choice. Yet, what finally matters is that Duncan's act of modifying the succession, his autocratic choice of an incompetent and immoral successor seem to closely resonate with the representation of the methods used by the Orbán administration in anti-loyal media.

So far it may have seemed that the political allusion in the insertion is somewhat didactic, and may seem an all too obvious wink at the audience, which in turn may well decrease the aesthetic quality of the production. The reason why this is not so needs contextualisation in three steps. First, I will briefly shed light on the relationship between the state and theatre companies in Hungary, especially from the financial perspective. In light of this, secondly, the location of the performance is also significant as well as, thirdly, the political layer in the performance. 
Politics is a delicate issue in the theatre in Hungary. This delicacy consists in a heritage concerning the financial system of theatres during the Socialist era. This heritage lies in bifurcation of two seemingly opposing factors: theatres and theatre companies have always been supported financially by the state since 1949, and theatres have always had the function of presenting the taboo, a refined way of criticising the political state of affairs. This continuity, however, has taken a variety of shades in the two historical periods.

During the Communist era, i.e., between 1949 and 1989, theatres were not only funded but strictly controlled by the state in a varying degree: more radically in the 1950 s and in the second half of the 1970s, less radically in the 1960s, early 1970s, and the 1980s. As Veronika Schandl points out: 'In exchange for their economic freedom, theatres, however, had to give up their political independence and were closely monitored as well as more or less strictly controlled by the Communist Party' (SCHANDL 2009: 9). This was the period of the three T's (Tiltás, 'Banning', Türés 'Tolerance', Támogatás 'Support'), when each production was checked by the authorities before its premiere. As far as the texts were concerned especially during the Kádár regime (1956-1989), what came into being is doublespeak, that is meaning was not only produced through the simple cooperation of the textual and the visual, but the audience was expected to differentiate between the audial and the visual text, and 'link the visual with the contemporary political discourse' (KISS 2008: 95). A side effect of this doublespeak was that the text did not matter so much, which in turn resulted in rather conservative textual politics, especially concerning texts in the literary canon, which Shakespeare's Hungarian translations were part of.

Similarly to the Socialist era, theatres and the emerging independent companies are nowadays financially supported to a varying degree by the state (stone theatres in a different manner than independent companies, because of which independent companies are more vulnerable). Nevertheless, this does not mean that politicians can intervene in the daily affairs of the theatres: both stone and art theatres as well as independent companies have maintained the tradition of including political references and criticism in their performances without consequences. Politics has intervened more at a rather abstract level, i.e., nominations for directors of theatres and the most prestigious national awards. No matter what political parties or coalitions were in power, this has been a practice, with recent studies showing that the more radical measures of the fourth Orbán administration have not destabilised theatrical life in terms of nominations, as members of the new elite also seek recognition by the entire theatrical community. By offering jobs to the old elite, 'the system fosters stabilisation' (KRISTÓF 2018: 57).

In harmony with the financial support of the theatre, another context may prove useful in deepening the meaning of a play, i.e., the location or locations of the production. Szikszai's production was designed for two types of theatres and for two cities: the production was first put on stage in a small, especially working-class town 60 kilometres from Budapest in a stone theatre, the Jászai Mari Theatre, Tatabánya, and after three months it was relocated to one of the most famous art theatres in Budapest, the Szkéné Theatre. Szikszai designed the stage accordingly, that is, it was created in a way that it 
would fit the Szkéné stage as well. The pragmatic reason for the relocation was that a production of a tragedy cannot have more than eight performances in Tatabánya, so if Szikszai intended a longer stage life for his production, the relocation after a few performances in Tatabánya to Budapest seemed inevitable.

This relocation of the production nicely lines up with a wider historical perspective. According to the database of the Hungarian Theatre Museum and Institute there were 34 productions of Macbeth between 1950 and 2019. If we plot a chart of locations and dates, a very interesting pattern emerges. In terms of the number of productions before and after the political changes, we see a doubling of Macbeth: while between 1950-1989 there were 13 productions, after 1989 there have been 21. Thus, there appears to be a growing interest in the tragedy that can readily convey political allusions after the fall of the Communist regime. It is also interesting that if we look at the locations, Budapest counts 12 productions whereas 22 productions were staged elsewhere in Hungary, which shows that politics and an interest in the classics was found in the theatres outside Budapest. The picture, however, becomes more refined if we look at the distribution of these productions according to places before and after the political changes. Before 1989, with three productions the town of Pécs was the winner of the imaginary Macbeth contest, with Budapest placing only second with two productions. After the fall, however, the scene radically changes with Budapest's 10 Macbeths, and Pécs comes second with two productions. So after 1989 the scene changes with a massive increase in Budapest, while the rest of the towns have shown neither a substantial increase nor decrease. These figures may point to the phenomenon that while theatres outside Budapest before 1989 were not scrutinised and controlled so vehemently, and then more potentially political plays could be produced in locations other than in Budapest, after the political changes Budapest has gained more significance. Naturally, other factors also have contributed to this phenomenon, such as the opening of small art theatres in Budapest after 1989. Still, judging from poll results during the general elections, it is also clear that it is Budapest that is opposed to the politics of the Orbán administration, and the party that is behind it, i.e., Fidesz. Szikszai's relocating the performance to Budapest from Tatabánya symbolically is in harmony with the tendency the figures above have signalled.

Once political allusions are at stake, the meaning of the performance can also be qualified with regards to the characters who function as the vehicle for the political allusion. The choices of the political characters have been Malcolm and Duncan, nicely presenting the changes in the political climate. In 2001, Róbert Alföldi directed a Macbeth in a small art theatre, the Budapest Chamber Theatre Tivoli. This production, which ran during the first Orbán administration, alluded to the political leadership with the character of Malcolm. In that production, after Macduff had killed Macbeth, Malcolm appears on the stage, guns his brother, Donalbain, down and says, 'our memory turns into hope, / And in Scone we are going to place the crown on our head, ${ }^{2}$ which reminded audiences of a slogan from the Fidesz campaign, linking 
the production to politics and Malcolm's doing away with possible contenders for his throne to the Orbán administration. Judit Csáki commented on this aspect of the play 'As it seems nowadays, there might be times when doing this takes artistic courage $[\ldots]$. But this is not that time. At this time, this bit of cheekiness slaps the production in the face' (CSÁKI 2001). In contrast with Alföldi's Macbeth, 17 years had passed, and during the time of the fourth Orbán administration in a Macbeth there was again an insertion, one which alluded to Orbán with Duncan instead of Malcolm. Thus, the shift lies in the movement from the politician who is at the beginning of his career to a politician who is at the end of his. The shift, however, undermines the clear-cut allusion in Alföldi's version to the extent that Duncan's assassination brings about worse and worse tyrants than Duncan had been. The insertion, thus, in a rather Shakespearean manner both undermines and supports the target of criticism in a most refined manner. In Alföldi's production, the new regime is worse than the previous one used to be. In Szikszai's version, besides the criticism of the Orbán administration, the hopes cannot be high, as the newcomers will be even worse. Whereas Alföldi was directly 'cheeky', in line with Shakespeare, Szikszai both criticises and indirectly supports those in power. The insertion, thus, does not close down the field of interpretation, 'does not only modify the original text, but [...] by the (theoretically infinite) chain of games, launches a series of associations and references' (IMRE 2005: 280), as Zoltán Imre argues.

What further qualifies the political allusion in the play that materialises in the insertion is the focus of the production. Instead of focusing on the political aspect of the Scottish tragedy, Szikszai's Macbeth devotes more attention to what happens inside the characters, and Szikszai masterfully visualises and puts on display what is inside. In a sense, clearly not purposefully, he follows the path which is nicely exemplified in Csaba Kiss' paper about his own direction of Macbeth at the National Theatre of Győr, 9 February 1996: 'I made this radical choice so that the emphasis should not be on the thirst for power, unlimited ambition, the coming into being of tyranny, but on the human losses that follow Macbeth's path, on the disappearance of friendships, on the spiritual emptiness that Macbeth and Lady Macbeth walk through from the day of victory to the complete alienation and ultimate fall' (KISS 2007: 131).

The only difference is that in Szikszai the focus is not only on the spiritual journey in general, but rather on the relationship between Macbeth and Lady Macbeth; it is their journey that is revealed to the audience. Their moments are the most cathartic on the stage: Macbeth's arrival at his castle and the Lady's bathing him, the playful and loving love-making, the nervous moments of Macbeth when he cannot just tell what is ailing him, the minute-long staring into each other's eyes through the distance. And all these aspects retrospectively change when at the end of the play Lady Macbeth unearths her dead child's corpse, the symbolic memento mori, the hopeless futurelessness of their life which has been buried and repressed thus far.

It is this unearthing and unleashing of the personal, the desperate, the unconscious emptiness that contextualises the political assertions of the production, which steer away from the bifurcation of political intentions. It is these two sides of the coin, 


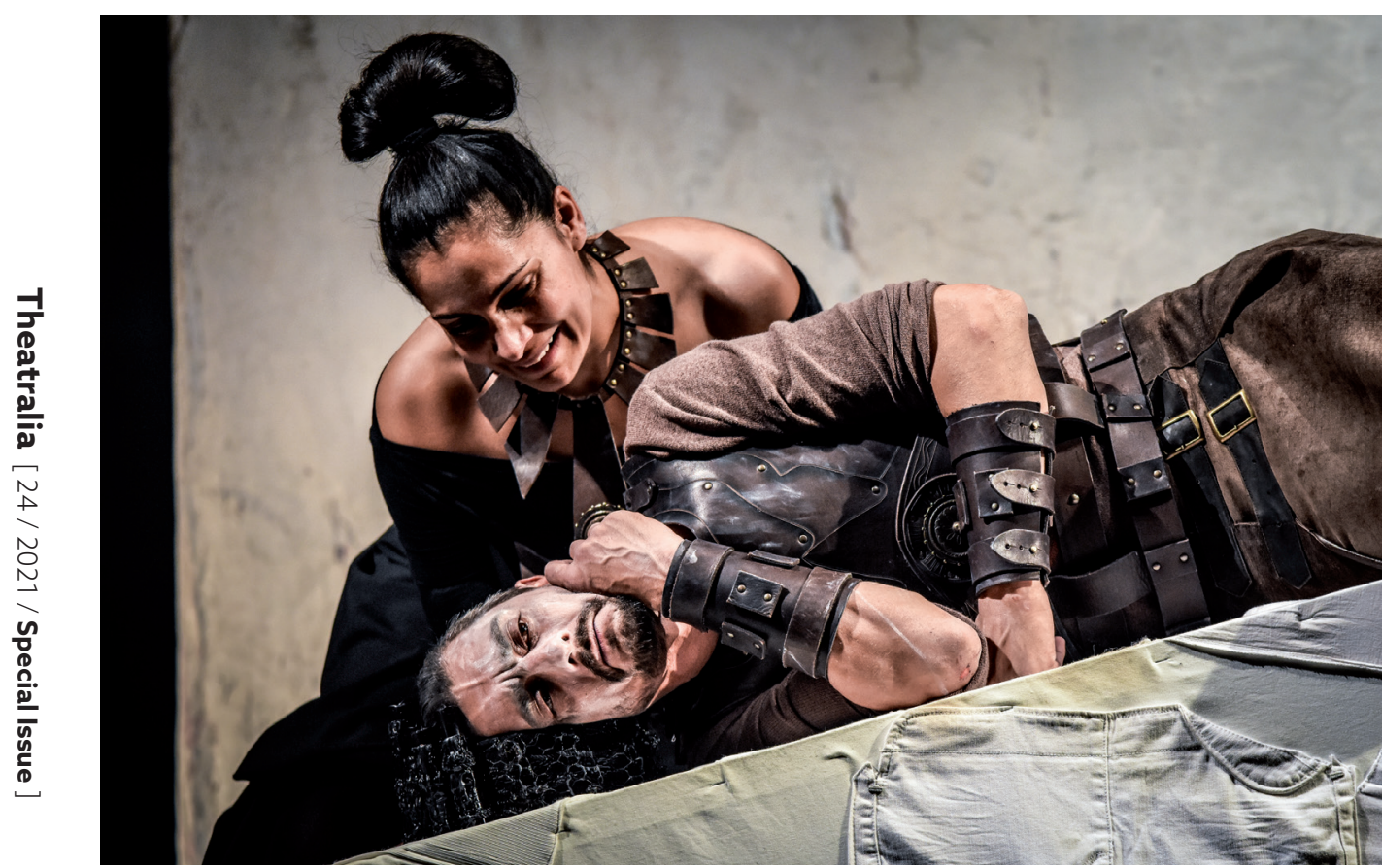

Fig. 2: Lídia Danis, Gábor Nagypál. Source: Jászai Mari Theatre, Violetta Prokl.

the emptiness inside, and the marginally presented politics that make the production powerful.

Although Rémusz Szikszai's Macbeth focuses on the relationship between Macbeth and Lady Macbeth, yet the political aspect of the play cannot be ignored either. Szikszai's insertion into Duncan's speech about the radical change in the method of succession with its rhetorical structure, religious, patriotic layers, and overconfident tone for a fleeting moment contextualises the play in the contemporary Hungarian political situation. This reference to the political world of the audience intricately harmonises with the heritage and identity of textual politics and wider cultural and theatrical tendencies in Hungary leading up to 2018. Szikszai's take on later political tendencies could be anchored in his III. Richárd betiltva [Richard III Banned] by Matei Vişniec (prem. 10 October 2020 in the Szkéné Theatre), but the exploration of this production goes beyond the scope of this article and this volume. 


\section{Bibliography}

CAUCHI, Francesca. 2015. 'Compunctious Visitings': Conscience as Unequivocal Witness in Macbeth. Philological Quarterly 94 (2015): 4: 335-351.

CSÁKI Judit. 2001. Színház: Malcolm Orbán Viktor? (A Macbeth a Tivoliban) [Theatre: Is Malcolm Viktor Orbán? (Macbeth in the Tivoli)]. Magyar Narancs 46 (2001). [accessed on 13.01.2021]. Available online at http://magyarnarancs.hu/zene2/szinhaz_malcolm_orban_viktor_a_ macbeth_a_tivoliban-56687.

IMRE, Zoltán. 2005. Szöveg-Előadás Lehetséges Kapcsolata a Kortárs (Magyar) Színházban [The Relationship between the Text and the Production in the Contemporary (Hungarian) Theatre]. Irodalomtörténet 36 (2005): 273-298.

IMRE, Zoltán. 2018. Theatre and Ideology: Staging The Merchant of Venice at the Hungarian National Theatre in 1940 and 1986. European Judaism 51 (2018): 2: 213-222.

INCZE, Tünde. 2003. Rejtett Terek a Macbethben [Hidden Places in Macbeth]. In István Géher and Attila Atilla Kiss (eds.). Az Értelmezés Rejtett Terei [The Hidden Places of Interpretation]. Budapest: Kijárat kiadó, 2003: 143-157.

KÁLLAY, Géza. 2002. Nem puszta kép [Not Merely an Image]. Budapest: Liget, 2002.

KISS, Csaba. 2007. 'Bár Magamról Ne Tudnék': Macbeth - Olvasás Rendezői Szemmel ['twere best not know myself': Macbeth - Reading with the Director's Eyes]. In István Géher and Katalin Tabi (eds.). 'Látszanak Mert Játszhatók': Shakespeare a Színpad Tükrében ['For they are actions that a man might play': Shakespeare in the Mirror of the Stage]. Budapest: ELTE, 2007: 131-150.

KISS, Gabriella. 2008. Magyar dráma és színház a 20. században [Hungarian Drama and Theatre in the $20^{\text {th }}$ Century]. Irodalomtörténet 39 (2008): 71-101.

KOLIN, Philip C. 1974. Macbeth, Malcolm, and the Curse of the Serpent. The South Central Bulletin 34 (1974): 4: 159-160.

KRISTÓF, Luca. 2018. Az Elitcsere Korlátai. Kultúrpolitika És Re-Putáció a Magyar Színházi Mezőben [The Limits of the Change of Elites. Politics of Culture and Re-Putation in the Hungarian Theatrical Field]. Szociológiai Szemle 28 (2018): 1: 33-59. [accessed on 13.01.2021]. Available online at http://real.mtak.hu/63432/7/kristof_szocszemle_elitcsere.pdf.

LEMON, Rebecca. 2002. Scaffolds of Treason in 'Macbeth'. Theatre Journal 54 (2002): 1: 25-43.

RADNÓTI, Zsuzsa. 2005. A Magyar Posztdramatikusok (Az Irodalmi Drámától Az Előadásszövegig) [The Hungarian Postdramatists (From Literary Drama to Playtext)]. Irodalomtörténet 36 (2005): 86: 257-266.

RAMSEY, Jarold. 1973. The Perversion of Manliness in Macbeth. Studies in English Literature, 1500-1900 13 (1973): 2: 285-300.

SCHANDL, Veronika. 2009. Socialist Shakespeare Productions in Kádár-Regime Hungary: Shakespeare behind the Iron Curtain. Lewiston: Edwin Mellen Press, 2009.

SHAKESPEARE, William. 1993. Hamlet Dán Királyfi Tragédiája [Tragedy of Hamlet, the Prince of Denmark]. Transl. by István Eörsi. Budapest: Cserépfalvi Kiadó, 1993.

SHAKESPEARE, William. 2006. Macbeth. Ed. by Barbara A. Mowat. [accessed on 13.01.2021]. Available online at https://msha.btk.ppke.hu/items/show/7. 
SHAKESPEARE, William. 2012. Shakespeare Három Dráma: Hamlet, Szentivánéji Álom, Lear Király [Shakespeare's Three Dramas: Hamlet, A Midsummer Night's Dream, King Lear]. Transl. by Ádám Nádasdy. Budapest: Magvető, 2012.

SZIKSZAI, Rémusz. 2018. Macbeth, avagy a skót darab [Macbeth, or the Scottish Play]. Playtext. Jászai Mari Theatre, Tatabánya.

TABI, Katalin. 2018. Hamlet: drámák és szövegkönyvek [Hamlet: Dramas and Playtexts]. Bárka 26 (2018): 15: 68-73. [accessed on 13.01.2021]. Available online at http://barkaonline.hu/esszektanulmanyok/6494-hamlet-dramak-es-szovegkonyvek-.

WOFFORD, Susanne L. 2017. Origin Stories of Fear and Tyranny: Blood and Dismemberment in Macbeth (with a Glance at the Oresteia). Comparative Drama 51 (2017): 4: 506-527.

ZITNER, Sheldon P. 1964. Macbeth and the Moral Scale of Tragedy. The Journal of General Education 16 (1964): 1: 20-28. 


\section{Zsolt Almási}

Department of English Literatures and Cultures, Institute of English and American Studies,

Pázmány Péter Catholic University

Mikszáth Kálmán tér 1., 1088 Budapest, Hungary

almasi.zsolt@btk.ppke.hu

ORCID: https://orcid.org/0000-0001-9405-8040

Zsolt Almási is an associate professor in the Institute of English and American Studies, Pázmány Péter Catholic University, Hungary. His book, The Problematics of Custom as Exemplified in Key Texts of the Late English Renaissance came off the press in 2004. He is a co-editor of journals International Journal of Digital Humanities and Digitális bölcsészet [Digital Humanities] and was co-editor with Mike Pincombe of the books Writing the Other. Humanism versus Barbarism in Tudor England (2008) and New Perspectives on Tudor Cultures (2012). He is the head of the Department of English Literatures and Cultures and an executive secretary of the Hungarian Shakespeare Committee. 